\title{
Táplálkozáspszichológia a tanácsadásban
}

\author{
VIDA KATALIN \\ ELTE Eötvös Loránd Tudományegyetem Pedagógiai és Pszichológiai Kar \\ Pszichológiai Tanácsadás Tanszék
}

(Beérkezett: 2019. január 12.; elfogadva: 2019. július 6.)

\begin{abstract}
Az utóbbi időben felvirágzó táplálkozáspszichológia (nutritional psychology) egyre növekvő számú kutatási eredménye támasztja alá a zöldség-, illetve gyümölcsfogyasztás és a mentális egészség közötti összefüggéseket. Az egyes tápanyagokat (pl. cink, folsav, B-vitamin, D-vitamin, ómega-3 zsírsav) vizsgáló kutatások eredményei szerint ezek a tápanyagok monoterápiaként használva egyértelmú eredményeket nem mutatnak. A jelenlegi ellentmondásos eredmények alól kivételt az ómega-3 zsírsav jelenthet, amellyel összefüggésben a legrobosztusabb eredményeket mutat a szakirodalom mind önálló, mind kiegészítő terápiaként. Ígéretes eredményeket a komplex étrendeket vizsgáló és a zöldség-, illetve gyümölcsfogyasztásra fókuszáló kutatások mutatnak. A zöldség-gyümölcs-bevitel, valamint a teljes kiőrlésú gabonák, hüvelyesek és olajos magvak fogyasztása pedig nemcsak a bennük található tápanyagok, hanem a rosttartalmuk miatt is kiemelkedő fontosságú, mivel ezek a tápanyagok az egészséges bélflórát biztosítják. Az elmúlt pár év eredményei a bélrendszer és az agy szoros összefüggését mutatják (ún. mikrobiom-bél-agy-tengely), jelezve, hogy az emésztőrendszer és a mentális egészség között szoros kapcsolat állhat fenn. Ezért a jelen tanulmány amellett érvel, hogy pszichológusként akkor is érdemes figyelembe vennünk a kliensünk étrendjét és az azzal kapcsolatos szokásait, ha nem ez áll tünetei fókuszában.
\end{abstract}

Kulcsszavak: táplálkozáspszichológia, mikrobiom, mikrobiom-bél-agy-tengely, depreszszió, szorongás, tanácsadás, pszichoterápia

\section{Bevezetés}

Az étkezéssel tanácsadás vagy pszichoterápia során leginkább akkor foglalkozunk, hogyha a kliens valamilyen evészavarról számol be, vagy komolyabb emésztéssel kapcsolatos tünetet hoz (pl. Crohn-betegség). A táplálkozás és pszichológia kölcsönhatásaival foglalkozó hazai kutatók is elsősorban evészavarokkal (anorexia nervosa, bulimia nervosa, falászavar) (pl. Kohlné Papp, 2016; Túry, Szumska, Pászthy, \& Purebl, 2017), elhízással (pl. (Lukács, 2017; Túry \& Czeglédi, 2017) vagy cukorbetegséggel (pl. Sal \&

\footnotetext{
* Levelezési cím: Vida Katalin, ELTE Eötvös Loránd Tudományegyetem Pedagógiai és Pszichológiai Kar Pszichológiai Tanácsadás Tanszék, 1064 Budapest, Izabella u. 46. E-mail: vidakatalin. mail@gmail.com
} 
Kohlné Papp, 2017) foglalkoznak. Nem véletlenül, hiszen ma Magyarországon mind az elhízás, mind a nem megfelelő táplálkozás komoly népegészségügyi probléma: a 16 éven felüli lakosság több mint felének súlytöbblete van: ezen belül 35,8\% túlsúlyos, 18,3\% enyhén elhízott, 1,4\% súlyosan elhízott személy (KSH, 2018). Az OECD (Gazdasági Együttmúködési és Fejlesztési Szervezet) 2017-es riportja kiemeli, hogy a világon a negyedik legelhízottabb ország vagyunk (OECD, 2017).

Az alábbi tanulmány ugyanakkor amellett igyekszik érvelni, hogy pszichológusként érdemes akkor is figyelembe vennünk a kliens étrendjét és az azzal kapcsolatos szokásait, ha nem ez áll tünetei fókuszában. Hiszen a 16 éven felüli lakosság $60 \%$-a nem fogyaszt naponta gyümölcsöt vagy frissen facsart gyümölcslevet, és 70\%-a nem fogyaszt naponta zöldséget vagy zöldséglevet (KSH, 2018). Pedig az utóbbi időben felvirágzó táplálkozáspszichológia (nutrition psychology ${ }^{1}$ ) égisze alatt születő kutatások sorra igazolják a zöldség-, illetve gyümölcsfogyasztás és a mentális egészség közötti összefüggéseket, végső soron alátámasztva azt az ősi meggyőződésünket, hogy az étkezésünknek és a hangulatunknak közük van egymáshoz.

\section{Kezdeti kutatások}

A táplálkozáspszichológiai kutatásokat három nagy csoportra lehet bontani: az egyes tápanyagra koncentráló, a szélesebb spektrumú tápanyagprofilt vizsgáló, valamint a teljes étrenddel foglalkozó vizsgálatok. Az egy adott tápanyag hatására fókuszáló kutatások, amelyek nagy mintán az adott tápanyag hiányát és a depressziós tünetek együttjárását vizsgálták, a folsav (Morris és mtsai, 2003; Sánchez-Villegas és mtsai, 2009), más B-vitaminok és az ómega-3 zsírsav (Murakami és mtsai, 2008) hatását támasztották alá.

Azok a vizsgálatok, amelyek ezeknek a tápanyagoknak az intervenciós lehetőségét vizsgálták depressziós klienseknél, Sarris, Schoendorfer és Kavanagh (2009) áttekintése szerint kevés bizonyítékkal rendelkeznek arra nézve, hogy ezek a tápanyagok monoterápiaként használva egyértelmú eredményeket mutatnának, de néhány tanulmányban kiegészítő terápiaként pozitív eredményeket hoztak folsav, S-adenozil-metionin (SAMe), ómega-3 zsírsav és L-triptofán esetében. Sarris és munkatársai (2016) pár évvel ezelőtti metaanalízisében megerősítette, hogy a SAMe, ómega-3 zsírsav, B9-vitamin aktív formája a levomefolsav és a D-vitamin kiegészítő terápiaként hatékonyan múködhetnek, de csak limitált eredményeket találtak

1 Az angol nyelvú szakirodalomban felváltva használják a „,nutrition psychology”, „,nutritional psychology" és a „nutritional psychiatry” kifejezéseket. A fogalom azt az új kutatási irányt foglalja össze, amelyben a táplálkozás és a mentális egészség közötti összefüggéseket vizsgálják. 
cink, folsav, C-vitamin és triptofán esetében. Más kutatóknak a legtöbb kiegészítő terápiaként használt nyomelemmel vagy vitaminnal összefüggésében egyelőre nem sikerült egyértelmú eredményeket kimutatniuk a depressziós tünetek javításában: Schefft, Kilarski, Bschor és Köhler (2017) nem talált a folsavval kapcsolatban egyértelmú hatást, míg a cinkkel igen, ugyanakkor a fent említett tanulmányban Sarris (2016) épp ellenkező eredményre jutott. A jelenlegi ellentmondásos eredmények alól kivételt az ómega-3 zsír$\mathrm{sav}^{2}$ jelenthet, amellyel összefüggésben a legrobosztusabb eredményeket mutat a szakirodalom (Mocking és mtsai, 2016) mind önálló (Sublette és mtsai, 2011), mind kiegészítő terápiaként (Sarris és mtsai, 2012).

Az összetettebb tápanyagprofillal dolgozó szerzők kiemelik, hogy tekintettel kell lenni a tápanyagok egymásra hatására (pl. önmagában a kalcium is jó egészségügyi hatásokkal bír, de magnéziummal és D-vitaminnal együtt fogyasztva nagyobb arányban szívódik fel; vagy pl. a B12-vitamin hiányában a sejtek megfelelő mennyiségú folsav rendelkezésre állása ellenére is folsavhiánnyal küzdenek) (Bezzegh, 2013), ezért nem volna szabad külön vizsgálni őket, ugyanakkor a szélesebb spektrumú tápanyagprofilt vizsgáló kutatások is többféle módszertani nehézséggel küzdenek, amelyekre később még visszatérek.

Éppen ezért a táplálkozáspszichológiai vizsgálatokban egyre inkább átkerült a hangsúly a komplex étrendendek vizsgálatára.

\section{Komplex étrendek vizsgálata}

Li és munkatársai (2017) metaanalízisükben 21, az étrend és a depresszió kapcsolatát vizsgáló kutatásból készítettek összevont, összegző elemzést. Eredményeik szerint az olyan egészséges étrend, amelyre nagymértékú gyümölcs, zöldség, teljes kiőrlésú gabona, hal, olívaolaj, alacsony zsírtartalmú tejtermékek és antioxidánsok, valamint alacsony mértékú húsfogyasztás a jellemző, a depresszió kockázatának csökkenésével jár együtt. Ezzel szemben a magas vörös és/vagy feldolgozott hús, a finomított gabonák, édességek, magas zsírtartalmú tejtermékek bevitele a depresszió kockázatának növekedésével jár együtt. Ezek az eredmények megerősítették Lai és munkatársai (2014) pár évvel korábbi metaanalízisét, amely szerint a nagymértékú gyümölcs-, zöldség-, teljes kiőrlésú gabona-, szárnyashús- és halbevitel, és az alacsony zsírtartalmú tejtermékek fogyasztása a depresszió kockázatá-

\footnotetext{
2 A szürkeállományunk kb. 50\%-át alkotják a többszörösen telítetlen zsírsavak, amelynek kb. 33\%-át az ómega-3 családba tartozó zsírsavak teszik ki. Mivel az ómega-3 ún. esszenciális zsírsav, az elóállítására a szervezet nem képes, tehát mindenképpen kívülről, táplálékként kell bevinnünk a szervezetünkbe (Popa \& Ladea, 2012).
} 
nak csökkenésével jár együtt. Le Port és munkatársai (2012) francia mintán végzett 10 éves utánkövetéses vizsgálatukkal is alátámasztották, hogy a hagyományos étkezési rend (magas gyümölcs-, zöldség- és halbevitel) és az étkezés rendszeressége szintén alacsonyabb rizikófaktort jelenthet a depresszióra (és ez az összefüggés az idő elteltével is fennmaradt).

Más összefoglaló tanulmányok kifejezetten a mediterrán diéta követése és a depresszió közötti fordított irányú összefüggést támasztják alá: a gyümölcs, zöldség, gabona, magok és hüvelyesek nagymennyiségú bevitele, a tejtermék, hal, szárnyas, tojás és telítetlen zsírsavak (mint az olívaolaj) mérsékelt fogyasztása, valamint az alacsony mértékú bor és feldolgozott hús bevitel akár 30\%-kal alacsonyabb rizikófaktort jelenthet a depresszióra (Psaltopoulou és mtsai, 2013). Hasonló eredményre jutottak más szisztematikus, összefoglaló tanulmányok is, ahol öt, a mediterrán diéta és a depreszszió kapcsolatát vizsgáló kutatásból négy esetben találtak a fentieknek megfelelő összefüggést (Rahe, Unrath, \& Berger, 2014).

Ezzel szemben a tipikus nyugati étrend (a telített zsírsavak, a finomított szénhidrátok és a feldolgozott ételek) magas bevitele rosszabb mentális egészségi mutatókkal jár együtt (Jacka és mtsai, 2010; O’Neil és mtsai, 2014; Rahe, Unrath, \& Berger, 2014). Megjegyzendő, hogy a szerző tudomása szerint egyetlen olyan tanulmány sincsen, amely szerint ez a fajta nyugati étrend a jó mentális egészséggel függne össze.

Habár az együttjárást vizsgáló kutatások rendszerint kontrollálják a potenciális háttértényezőket, mint amilyen az anyagi helyzet és az iskolázottság, a feltárt összefüggés mögött olyan nem mért tényezók is lehetnek, mint hogy a depressziós személyek jobban is kívánják és nagyobb arányban is viszik be a magas szénhidrát- és zsírtartalmú ételeket (Christensen, 2001), míg a jobb hangulatban lévő személyek nagyobb eséllyel választanak egészséges ételeket (Gardner, Wansink, Kim, \& Park, 2014).

Ezért is fontos, hogy a közelmúltban dr. Felice Jacka vezetésével ausztráliai kutatók nem csupán megfigyelték az emberek étkezési szokásait és statisztikailag összevetették a mentális egészségükre vonatkozó adatokkal, hanem a depresszió és az étrend közötti összefüggést randomizált kontrollált kísérlet (RCT) alá is vetették és elindították az ún. SMILES kutatási projektet (Jacka és mtsai, 2017). Így vizsgálhatóvá tették a depresszió és az étrend közötti oksági kapcsolatot is. A kísérletben résztvevő, depressziótól szenvedő és alapvetően nem-egészségesen étkező személyeket $(n=67)$ véletlenszerúen beosztották két csoportba és az egyik csoportnak (intervenciós csoport) egy 12 hetes speciális étrendet írtak elő (amelyet 7 alkalmas egyéni dietétikai tanácsadással támogattak meg), míg a másik csoport ez idő alatt csupán társas támogatást kapott (kontroll csoport).

Az intervenciós csoport étrendjében a kiegyensúlyozottságra és a könynyen követhetőségre törekedtek, kifejezetten kiemelve, hogy a résztvevők 
annyit egyenek, amennyi jól esik, mivel a cél nem a fogyás, hanem a kiegyensúlyozott táplálkozás volt. A 12 hetes program a következő étrendi elemekből épült fel: teljes kiőrlésú gabonák (naponta 5-8 alkalommal); zöldség (naponta 6 alkalommal); gyümölcs (naponta 3 alkalommal); hüvelyesek (hetente 3-4 alkalommal); alacsony zsírtartalmú, hozzáadott cukor nélküli tejtermékek (naponta 2-3 alkalommal); nyers és sótlan magvak (naponta egyszer); halak (heti kétszer); sovány vörös húsok (hetente 3-4 alkalommal); csirke (hetente 2-3 alkalommal); tojás (hetente legfeljebb 6 alkalommal); olívaolaj (naponta 3 evőkanál); cukrozott üdítóitalok, iparilag feldolgozott húsok, gyorséttermi ételek (legfeljebb heti háromszor). Az eredményeik szerint a 12 hetes étrendben részt vett vizsgálati személyek szignifikánsan kevesebb depressziós tünetról számoltak be a program indulásához és a kontroll csoporthoz képest is (akiknél ugyan szintén csökkent a depresszió mértéke, de nem ilyen nagy mértékben).

Ugyanabban az évben a Nutritional Neuroscience-ben egy hasonló, de nagyobb elemszámú $(n=152)$ és hosszabb ideig tartó szintén RCT vizsgálatot publikáltak (Parletta és mtsai, 2019). A kutatásban az intervenciós csoportba tartozó személyek három hónapon keresztül kéthetente részt vettek egy csoportos foglalkozáson, ahol főzni tanították óket, valamint biztosították számukra az egészséges étrendhez szükséges alapanyagokat, míg a másik csoport a SMILES kutatáshoz hasonlóan ez idő alatt csupán társas támogatást kapott (kontroll csoport). Az eredmények hasonlónak bizonyultak: mindkét csoportban csökkentek a depressziós tünetek, de az intervenciós csoportban 1,7-szer nagyobb mértékben a kontroll csoporthoz képest.

\section{Fókuszban a zöldség- és gyümölcsbevitel}

A mediterrán diéta mellett sokféle más étrend is létezik, mint például alacsony szénhidráttartalmú diéta (pl. Atkins-diéta), alacsony zsírtartalmú diéta (pl. vegetáriánus étrend), alacsony glikémiás indexú diéta, paleolit diéta, vegán diéta, vegyes diéta. Így azután jogosan merülhet fel a kérdés, hogy egészségesebbnek számít-e valamelyik. Katz és Meller (2014) összefoglaló tanulmányának eredményei szerint jól azonosítható módon két tényező emelkedik ki a szakirodalomból, amely meghatározója az egészséggel kapcsolatos összefüggéseknek: (1) az elsősorban növényi alapú étkezés (zöldséggyümölcs-fogyasztás ${ }^{3}$ mellett ide értve a teljes kiőrlésú gabonákat, hüvelyeseket és olajos magvakat), és (2) a természetes, iparilag minél kevésbé

\footnotetext{
3 Az angol nyelvú irodalomban „fruit and vegetable intake” vagy „FVI”-ként utalnak a bevitt zöldség-gyümölcs arányra.
} 
feldolgozott táplálék aránya. Ezt a tanulságot fogalmazta meg évekkel korábban Micheal Pollan (2008) a médiában is híressé vált mottójában: „Eat food. Not too much. Mostly plants.”, azaz „Egyél ételt, ne túl sokat, fóként növényeket"!

A bevitt zöldség-gyümölcs-arány szoros összefüggést mutat a mentális egészséggel is: azok, akik több zöldséget és gyümölcsöt fogyasztanak, kevesebb mentális zavarral küzdenek, ideértve a depressziót, az észlelt stresszt és a negatív hangulatot (Akbaraly és mtsai, 2009; Bishwajit és mtsai, 2017; Ford, Jaceldo-Siegl, Lee, Youngberg, \& Tonstad, 2013; Gopinath, Flood, Burlutksy, Louie, \& Mitchell, 2016; Jacka, Mykletun, Berk, Bjelland, \& Tell, 2011; Jacka és mtsai, 2017, 2010; Li és mtsai, 2017; McMartin, Jacka, \& Colman, 2013; Mikolajczyk, El Ansari, \& Maxwell, 2009; Trichopoulou és mtsai, 2003). Emellett magasabb arányban számolnak be boldogságról (Lesani, Mohammadpoorasl, Javadi, Esfeh, \& Fakhari, 2016), jó hangulatról (Ford és mtsai, 2013; White, Horwath, \& Conner, 2013), és élettel való elégedettségről (Blanchflower, Oswald, \& Stewart-Brown, 2013; Mujcic \& Oswald, 2016).

A zöldség-gyümölcs-bevitel és a mentális egészség közötti összefüggés ráadásul dózis-függőnek túnik, tehát minél magasabb a bevitel, annál jobb mentális egészségról számolnak be a vizsgálati személyek (Blanchflower és mtsai, 2013). Mujcic és Oswald (2016) közel 13000 fós ausztrál longitudinális kérdőíves vizsgálatukban azt találták, hogy azok a megkérdezett személyek, akik két év alatt „alacsony”-ról „magas” zöldség-gyümölcs-bevitelre mozdultak el, annyival növekedett az élettel való elégedettség pontszámuk, mint amekkorát a munkanélküliségből a munkába állás hozott volna.

A zöldség-gyümölcs-fogyasztás kapcsán felmerül a kérdés, hogy nyersen vagy főzve gyakorol jobb hatást a mentális egészségre. Hőkezelés során a zöldségek, gyümölcsök elvesztik bizonyos vitamintartalmukat, ez különösen igaz olyan vízben oldódó vitaminokra, mint a C- és B-vitamin. Brookie, Best és Conner (2018) 422 fóvel végzett kérdőíves kutatásukban azt találták, hogy a nyers zöldség-gyümölcs-fogyasztás még a szocioökonómiai státusz kontrollálása mellett is kimutathatóan összefüggött az alacsonyabb depreszsziós pontszámmal, magasabb hangulat pontszámmal, nagyobb élettel való elégedettséggel, míg az elfogyasztott fơtt zöldség-gyümölcs-fogyasztás csupán a jó hangulattal mutatott szignifikáns összefüggést. Ezért tanulmányukban kifejezetten a nyers zöldségek és gyümölcsök fogyasztása mellett érvelnek. Ugyanakkor bizonyos antioxidánsok, mint például a répában található béta-karotin (az A-vitamin provitaminja), pont a sütés-fózés során szabadul fel nagyobb arányban a sejtfalakból és így nagyobb arányban hasznosulnak az emberi emésztőrendszerben (Livny és mtsai, 2003). Ugyanez igaz egy másik karotionoidra, a paradicsomban található likopinra is. A paradicsom feldolgozott formájában (pl. paradicsomszószként) 
kétszer-háromszor több likpoint is tartalmazhat a nyers paradicsomhoz képest (Dewanto, Wu, Adom, \& Liu, 2002). Turkmen, Poyrazoglu, Sari és Velioglu (2006) eredményei szerint más zöldségek (pl. zöldbab, spenót, brokkoli) esetében is az enyhe hőkezelés - mint amilyen a gőzölés -, összességében növeli az antioxidáns-aktivitást. Az ásványi anyagokat tekintve szintén vegyes képet kapunk: gabonafélék és hüvelyesek esetében a hőkezelés csökkenti a hozzáférhetó cink tartalmat, ugyanakkor növeli a biológiailag hasznosuló vas mennyiségét (Jing, Yuwei, Zhenping, \& Qian, 2017). A mentális egészség szempontjából az eredmények tehát arra utalnak, hogy az optimális múködéshez antioxidánsokra van szükségünk, érdemes tehát nyersen és főzve is fogyasztani zöldséget és gyümölcsöt, hogy mind vitaminokból, mind karotionoidokból, mind ásványi anyagokból kiegyensúlyozott mennyiségben vigyünk be a szervezetünkbe.

A zöldség-gyümölcs-bevitel valamint a teljes kiőrlésú gabonák, hüvelyesek és olajos magvak fogyasztása pedig nemcsak a bennük található tápanyagok, hanem a rosttartalmuk miatt is kiemelkedő fontosságúak ${ }^{4} \mathrm{Nem}$ csupán arról lehet szó, hogy egy összetett és kiegyensúlyozott étrend a megfelelő tápanyaghoz juttatja az egyik legfontosabb szervünket, az agyunkat, hanem arról is, hogy az elfogyasztott táplálék a bélrendszerünkön keresztül, közvetve is hat a mentális egészségre (Jacka, 2018). A rostok olyan növényi eredetú szénhidrátok, amelyeket a szervezetünk nem képes megemészteni, ezért eljutnak a vastagbélbe. Annak ellenére, hogy számunkra emészthetetlenek, elsődleges tápanyagot jelentenek az emésztőrendszerben található több millió baktériumnak, gombának és egyszerú egysejtúeknek (Sawicki és mtsai, 2017).

\section{A mikrobiom-bél-agy-tengely}

A bennünk és rajtunk élő mikrobióták pontos száma jelenleg is szakmai vita tárgya, de minden bizonnyal az emberi szervezet legalább annyi, vagy még több baktériumot tartalmaz, mint ahány sejtje van. Korábbi tanulmányok - feltehetőleg még az 1970-es évekbeli adatokból kiindulva - ezt az arányt akár 10:1-re is becsülték (Knight \& Buhler, 2015), ma már inkább 1,3:1 arányt tartják iránymutatónak (Sender, Fuchs, \& Milo, 2016). Sőt, DNS-ben mérve a mikrobióták sokszínúsége és jelentősége még szembetúnőbb:

\footnotetext{
4 Az Egészségügyi Világszervezet (World Health Organization - WHO) (WHO Report, 2003) és az amerikai The Institute of Medicine's (Institute of Medicine, Food and Nutrition Board, 2002) napi 25-38 g élelmi rost fogyasztását javasolja felnőttek számára. Hazánkban a férfiak átlagfogyasztása $(25,0 \mathrm{~g} /$ nap) megközelíti, míg a nók fogyasztása (20,8g/nap) nem éri el ezt a mennyiséget (Szeitz-Szabó, Bíró, Bíró, \& Sali, 2011).
} 
kb. 20000 emberi génnel rendelkezünk, míg a mikrobiális gének száma 2 milliótól 20 millióig terjed, tehát genetikai értelemben 99\%-ban mikrobákból állunk (Gilbert és mtsai, 2018). Össztömegüket a 2008-ban indult Human Mikrobiom Projekt ${ }^{5} \mathrm{~kb} .1$ és 2,5 kg közé becsüli.

Jelen tanulmány csak a bélrendszer mikrobiális ökoszisztémájára fókuszál. Mai ismereteink szerint az összes baktériumsejt 90\%-a itt található (a székletben a baktériumszám $10^{11}-10^{12} / \mathrm{ml}$ lehet). Ez az óriási tömegú mikroorganizmus tulajdonképpen egy kiterjesztett genomot, multigenomikus szimbiózist jelent, ekképpen az ember egy komplex biológiai „,szuperorganizmus"-nak tekinthetó, ahol az anyagcsere-szabályozás egy része lenyúgöző módon átkerül a velünk szimbiózisban élő mikrobióták felelősségébe (Bíró, 2014).

Ily módon a mikrobióták kölcsönhatásban állnak az emberi gazdasejtekkel, jelentősen befolyásolják az anyagcserét és az immunválaszokat (Belkaid \& Hand, 2014). A mikroba és a genom szó összevonásával mikrobiomként emlegetett éló tömeget egyes kutatók már az emberi szervek közé sorolják, és mostanában kezd kiderülni, mennyire fontos szerepe van nemcsak a testi folyamatokban, de akár az idegrendszer múködésében is (Clapp és mtsai, 2017; Malan-Muller és mtsai, 2018). Így az elmúlt években azonosított bél-agy-tengelyre ma már inkább mikrobiom-bél-agy-tengelyként („microbiom-gut-brain axis") hivatkozik az irdalom.

A bélrendszer mikroflórája a születés után fokozatosan alakul ki. Az első héten korlátozott számú törzs mutatható ki és a mikrobiológiai közösség meglehetősen instabil, az első hónap során gyakran jelentős változások történnek. Vaginális szülésnél az újszülöttnél azok a törzsek dominálnak amelyek az anya hüvelyi flórájában találhatóak (Lactobacillus, Prevotella, vagy Sneathia törzsek), hiszen az újszülött a steril méhből kikerülve itt „találkozik" először a későbbi élete során létfontosságú mikrobiótákkal. ${ }^{6}$ Felnőtt korra a bélrendszerben már legalább 1200 féle mikroorganizmus él, és az egyének között a bélflóra összetételében nagy eltérések lehetnek (Dave, Higgins, Middha, \& Rioux, 2012).

\footnotetext{
5 A Humán Mikrobiom Projektet (HMP) az amerikai National Institute of Health hívta életre, amelynek célja, hogy új, nagy hatékonyságú molekuláris biológiai módszerekkel, mint amilyen az újgenerációs szekvenálás, részletesen feltérképezze a teljes humán ökoszisztémát, továbbá, hogy megállapítsa a különböző kóros elváltozásokat kísérő mikrobiom-alterációkat. További információ: https://www.hmpdacc.org/overview/

${ }^{6}$ A gyomor-bél-rendszer a születés utáni első napokban kolonizálódik a pár éve még normálisnak tartott vaginalis flórával. Újabb cikkek már eltérnek ettól, felismerve, a nyugati orvostudomány által beöntésekkel előkészített és az egész gáttájat fertőtlenítő szüléstechnika hátránya, hogy az újszülött nem találkozik az anya székletével és így bélflórájával (Frecska \& Móré, 2018) Ez még inkább igaz a császármetszéssel született gyerekekre, akiknek a béltraktusának normális betelepítése több hetet, hónapot késhet és esetükben az első hetekben a bőrflóra képviselői (Staphylococcus, Corynebacterium, Propionibacterium) telepednek meg először (Bíró, 2014).
} 
A mikrobiom összetételének a pontos feltárása csak az utóbbi évtizedekben kezdődött. Egy új genetikai vizsgálati módszer, a DNS-szekvenálás hatalmas fejlődése és olcsóbbá válása tette csak lehetővé a mikrobiom precíz feltárását, mivel a mikrobák többsége a hagyományos módszerrel, azaz laboratóriumban, Petri-csészében kitenyésztve nem vizsgálhatóak - ezek az élőlények az emberi testen kívül nem élnek meg. Ezért a hangulattal, mentális egészséggel kapcsolatos eredmények is csak az elmúlt két-három évben születtek.

Az egyik fontos vizsgálati aspektus a mikrobiom diverzitása. Diverzitás alatt egyfelól a bélflóra gazdagságát, másfelól az egyenletességet értjük. Az egyenletesség fogalma azt írja le, hogy ha veszünk két mintát, amiben ugyanannyi baktérium található (tehát ugyanannyira gazdagok a minták), az egyikben lehet, hogy mindegyik baktériumtörzsből ugyanannyi darab van, míg a másik mintában néhány baktériumtörzsből sok van, míg másokból kevesebb. Tehát a két minta különbözik az egyenletesség tekintetében. Ez pedig azért fontos szempont számunkra, mert - mint minden ökoszisztéma - a mikrobiom is annál egészségesebb és ellenállóbb, minél nagyobb biodiverzitással jellemezhető (Knight, Metcalf, \& Amato, 2018).

Minél több faj van egyszerre jelen, annál többféle funkciót tudnak ellátni. Ezért egy diverz ökoszisztéma több mindenre képes és jobban is tud alkalmazkodni a környezeti változásokhoz. A nagyobb diverzitás funkcionális redundanciát is jelent: minél több faj van jelen, annál valószínúbb, hogy két faj hasonló feladatokat lát el. Ez pedig védettséget jelent a teljes ökoszisztéma számára: ha az egyik faj kihalna, a másik továbbra is ellátja ugyanazokat a funkciókat. Nem utolsó sorban a diverz rendszerek a külső támadásokkal szemben is ellenállóbbak, mivel egy jól múködő, komplex rendszerben a különböző fajok az összes rendelkezésre álló erőforrást felhasználják, ezért a külső patogéneknek nincs lehetóségük megtelepedni. Mivel pedig a bennünk élő mikrobák roston élnek, minél több rostokban dús zöldséget és gyümölcsöt fogyasztunk, annál diverzebb és ebből következően annál ellenállóbb lesz a bélflóránk (Knight és mtsai, 2018).

Amikor az emberek rostokban gazdag ételeket fogyasztanak, a rostok fermentálódnak a bélben rövid láncú zsírsavakat hozva létre, amelyek szabályozzák az immunrendszert és befolyásolják a génexpressziót az agyban és más területeken. Akik elég rostot fogyasztanak, diverzebb mikrobiommal rendelkeznek. ${ }^{7}$ Ezek a baktériumok különböző vegyi anyagokat hoznak létre, amelyek különböző kölcsönhatásokon keresztül befolyásolják a hangulatunkat (Rogers és mtsai, 2016).

\footnotetext{
7 A mikrobiom összetételére ugyanakkor nemcsak étkezés, hanem az életmód, a genetikai háttér, a korai kolonizáció, gyógyszeres kezelés és egyéb betegségek is hatással lehetnek (Graf és mtsai, 2015).
} 
A gyorséttermi, illetve magas cukortartalmú ételek fogyasztása és a depresszió közötti összefüggésre több tanulmány eredményei is rávilágítottak már (Jacka és mtsai, 2010; Mikolajczyk és mtsai, 2009; Sánchez-Villegas és mtsai, 2012). A bélflóra állapota az említett összefüggés közvetító tényezője lehet, mivel a tipikus nyugati étrend (a telített zsírsavak, a finomított szénhidrátok és a feldolgozott ételek nagyobb aránya miatt) rombolja a bélflórát (Zinöcker \& Lindseth, 2018).

A mikrobiom sokféleségét jól mutatja, hogy habár tudjuk, hogy az emberek genetikai állománya 99,99\%-ban megegyezik, ez egyáltalán nem mondható el a mikrobiomunkra. Ugyan eleinte azt feltételezték a kutatók, hogy van egy mindenkiben megtalálható alap mikrobiom „mag”, az utóbbi idők kutatási eredményei bebizonyították: nincs egyetlen olyan mikrobiom faj sem, amely a világ összes táján élő minden emberben megtalálható volna. A mikrobiomunk összetétele tehát személyenként eltérő, ebből a szempontból az ujjlenyomathoz hasonlatos lehet (Knight, 2014). Egyelőre nem tudjuk megmondani, hogy mi az a konkrét bélflóra-összetétel, ami az egészséges mikrobiomot jelenti. Azt tudjuk megállapítani, hogy ha a bélflórát azon a szinten vizsgáljuk, hogy összességében hogyan funkcionál, akkor megtaláljuk a metabolikus aktivitásnak azt a „közös magját”, amely egy egészséges bélflórára, mint egészre jellemző. Az esőerdőkhöz hasonlóan, amelyeket a világ különböző pontjain nagyon különböző fajok alkotnak (és nem lehet azonosítani olyan fajokat, amelyek az esőerdo „esszenciáját” képeznék) saját egyedi növény- és állatviláguk ellenére hasonlóan funkcionálnak. Ahogy az esőerdőkben, úgy a bélflóránkban is a „közös mag” funkcionális szinten van és nem az egyes tagok szintjén (Knight \& McDonald, é.n.). ${ }^{8}$

A mikrobiom-bél-agy-tengely, vagyis a bélflóra, bélrendszer és a mentális egészség közötti pontos kölcsönhatás sem tisztázott még. Többféle mechanizmus is lehetséges: (1) A bélbaktériumok maguk is termelnek olyan fontos neurotranszmittereket (szerotonin, dopamin), amelyek felszívódása kihat a hangulatra (Lyte, 2013). (2) Más organizmusok viszont lebontják és ezen keresztül szabályozzák a neurotranszmitterek mennyiségét (O’Mahony, Clarke, Borre, Dinan, \& Cryan, 2015). (3) Néhány mikroba aktiválni tudja a nervus vagus-t (bolygóideget), amely a paraszimpatikus

\footnotetext{
8 Megjegyzendő ugyanakkor, hogy 2011-ben a Nature-ben publikált kutatás alapján azt már tudjuk, hogy a bél mikroflórája fóleg 3 enterotípusból áll: Prevotella, Bacteroides és Ruminococcus. A Prevotella elsősorban a szénhidrát- és egyszerúcukor-alapú étrenddel kapcsolatos, amely a mezőgazdasági társadalmakra jellemző. A Bacteroides enterotípus dominanciája az állati eredetú fehérjét, aminosavakat és telített zsírokat tartalmazó nyugati étrenddel függ össze. Egy bizonyos enterotípus túlsúlya tehát utal a táplálék összetételére (Arumugam és mtsai, 2011). Az összetétel pontosítása folyamatosan zajlik, ebben az évben az alaptípusokat szélesítették az eljárások tökéletesítése miatt (Rinninella és mtsai, 2019).
} 
idegrendszer részeként a megnyugvásért felel (Bonaz, Bazin, \& Pellissier, 2018). Végül (4) egyes mikrobák hatással vannak az immunrendszerre és így közvetetten is hatnak a hangulatunkra (El Aidy, Dinan, \& Cryan, 2015).

Ez a jelentősen új kutatási irány még csak most kezd kibontakozni, és rengeteg kérdéssel kapcsolatban még nincsenek egyértelmú válaszaink. A mikrobiom a következő években várhatóan meghatározó kutatási területe lesz a fizikai és mentális betegségeknek is (Knight, 2014).

Összefoglalva tehát a mentális állapotunk szempontjából egészséges étrendnek egyfelől biztosítania kell a tápanyagokat, amire az agyunknak szüksége van, másfelól támogatnia kell a változatos és egészséges bélflóránkat is (Mosconi, 2018).

\section{Táplálkozáspszichológiai intervenciók}

\subsection{Az egy tápanyagot vagy tápanyagprofilt vizsgáló intervenciós kutatások}

Az elmúlt években felgyülemlett táplálkozáspszichológiai összefüggéseket egyre több mentális betegség kapcsán igyekeznek átültetni a gyakorlatba is. Az egy tápanyagot vagy tápanyagprofilt vizsgáló intervenciós kutatások eredményei egyelőre ellentmondásos eredményeket hoztak. ${ }^{9}$ Az egy tápanyagra fókuszáló kutatások közül Mary A. Fristad és kutatócsoportja (Fristad és mtsai, 2019) évek óta az ómega-3 zsírsav hatását vizsgálják. ${ }^{10}$ Egy RCT vizsgálatukban 72 depresszióval diagnosztizált gyereket osztottak be négy különböző vizsgálati csoportba: egy részük 12 hétig ómega-3 zsírsav kezelést kapott, egy részük ómega-3 zsírsav mellett pszichoterápiás ellátásban részesült, egy részük pszichoterápiában részesült és mellette placebót kapott, és egy részük csak placebót kapott. Azoknak, akik ómega-3 zsírsav + pszichoterápiás ellátásban részesültek, 77\%-a ért el tünetmentes állapotot, szemben azzal az 56\%-kal, akik csak placebót kaptak. Megjegyzendő, hogy sem a csak ómega-3 zsírsav, sem a csak pszichoterápia feltételhez képest nem, csupán a placebó feltételhez képest volt szignifikáns az eredmény. Egy másik kutatásukban azonban, ahol szintén az ómega-3 zsírsav hatását vizsgálták ezúttal magatartásproblémás gyerekeknél, azt találták, hogy azok a gyerekek, akik ómega-3 zsírsavat kaptak - függetlenül attól, hogy

\footnotetext{
9 E vizsgálatok nem ritkán nagyobb gyógyszergyárak finanszírozásával készülnek. A B-vitamin komplexumok szorongással kapcsolatos kutatásait nem egy esetben a Bayer gyógyszergyár finanszírozta (Kennedy és mtsai, 2010), vagy a tanulmányok szerzói nagyobb gyógyszergyártó cégek tanácsadói testületeinek tagjai (pl. Vesco, Young, Arnold, \& Fristad, 2018).

10 A vizsgálatokban az ómega-3 szírsavat kapszula formájában biztosítják.
} 
önmagában vagy pszichoterápia kíséretében -, valóban szignifikáns javulást mutattak a hiperaktivitás és az impulzivitás tekintetében, mint azok, akik placebót kaptak (pszichoterápiával vagy anélkül) (Young, Arnold, Wolfson, \& Fristad, 2017).

A figyelemhiányos hiperaktivitás-zavar (ADHD) kapcsán az eredmények egyelőre szintén nem tûnnek egyértelmúnek. Julia J. Rucklidge és munkatársai (Rucklidge, Frampton, Gorman, \& Boggis, 2014) egy RCT vizsgálatban 80 ADHD-vel diagnosztizált felnőttet soroltak két csoportba: az egyik csoport egy szélesspektrumú tápanyagformulát kapott, a másik csoport placebót. Nyolc héttel később a klinikai diagnózis mellett mind a kísérleti alanyok, mind a házastársaik értékelték az ADHD tüneteiket. A klinikusok által végzett diagnosztikai mérésekben nem volt különbség a két csoport között, ugyanakkor az ön- és házastársi megfigyelésekben a kliensek nagyobb mértékú tünetcsökkenésről számoltak be a placebo csoporthoz képest.

Rucklidge és kutatócsoportja (2012) földrengést követő poszttraumás stressz szindrómás (PTSD) személyeket is vizsgált. 91 olyan személyt vontak be a vizsgálatba, akik 2-3 hónappal a földrengés után is a szorongás jeleit mutatták. Három csoportba osztották őket, egy részük B-vitamin komplexumot, egy részük magas dózisú, egy részük pedig alacsony dózisú szélesspektrumú tápanyagformulát kapott. A szélesspektrumú tápanyagformulát kapó személyek (függetlenül a dózistól) kevesebb betöró gondolatról számoltak be a B-vitamint szedőkhöz képest; azok pedig, akik magas dózisban szedték a szélesspektrumú tápanyagformulát, jobb közérzetről és kevesebb szorongásról számoltak be, mint a B-vitamin komplexumot szedők. Ugyan minden egyes kísérleti személy jobban lett a kontroll csoporthoz képest, akik semmilyen kezelésben nem részesültek, de a kísérleti elrendezésben nem szerepelt placebo csoport, így nem lehet kizárni annak a lehetőségét, hogy a hatást a gondoskodás gesztusa hozta.

\subsection{Teljes étrendet érintő intervenciók}

Az egyes tápanyagokat vagy tápanyagprofilokat vizsgáló kutatásoknak a teljes étrendet vizsgáló intervenciókkal szemben több módszertani és elméleti hátrányuk is van. (1) Az emberek nem esznek egyesével elkülönített tápanyagokat. Ehelyett többféle hozzávalóból készült ételeket esznek, amelyekben egymással kölcsönhatásban álló, összetett kombinációban találhatóak meg a tápanyagok. Az egy tápanyagra fókuszáló kutatások nem veszik figyelembe, hogy hogyan hatnak ezek az anyagok egymásra a szervezeten belül (pl. a fentebb említett példában a folsav és a B12 vitamin esetében). 
(2) A nagymértékú egymásra hatások miatt nehéz az egyes tápanyagok hatását külön és precízen mérni. (3) Egy adott tápanyag hatása valószínúleg önmagában olyan alacsony, hogy külön nem is mérhető, szemben egy teljes étrendi mintázat hatásához képest. (4) Az egy-egy tápanyagra koncentráló kutatások eredményei közegészségügyi szempontból is nehezebben értelmezhetőek, az általánosabb szempontokat megfogalmazó, a teljes étrendre fókuszáló étkezési iránymutatások a nyilvánosság számára közérthetőbbek (Hu, 2002). A komplex étrendet célzó intervenciók további előnye, hogy az évezredek alatt kialakult étrendekben ezek a tápanyagok a megfelelő egyensúlyban, egymással kiegészülve kerülnek a szervezetünkbe (Popa \& Ladea, 2012), biztosítva nemcsak az elégséges mikrotápanyag-, hanem rostbevitelt is (Del Chierico, Vernocchi, Dallapiccola, \& Putignani, 2014). Ráadásul a beszedett kapszulák helyett az étellel és fózéssel való aktív foglalkozás, mint az öngondoskodásnak egyik formája jobb önértékelést, nagyobb magabiztosságot és nagyobb kontrollérzetet hozhat magával (Farmer, Touchton-Leonard, \& Ross, 2018).

A teljes étrendet vizsgáló randomizált kontrollált kísérletek (RCT) különösen gyermekcipőben járnak még és költséges a megvalósításuk. Ugyanakkor az eredményeik ígéretesek. A tanulmány elején említett Jacka és munkatársainak (2017) SMILES kutatási programján kívül, a szintén említett HELFIMED projekt nagyobb elemszámmal $(n=152)$ megismételte Jacka-ék kutatási elrendezését és eredményeik megerősítették az eredeti elképzeléseket a mediterrán diéta és a mentális egészség összefüggéseiról (Parletta és mtsai, 2019).

Összefoglalva tehát a klienseink mentális állapota szempontjából érdemes a komplex étrendet érintő intervenciókra fókuszálnunk, amelyek nem csupán biztosítják tápanyagokat, hanem támogatják a változatos és egészséges bélflórát és az aktív öngondoskodást segítik elő.

\section{Az egyéni tanácsadásban megfontolandó szempontok}

A hozzánk forduló kliensek gyakran instabil állapotban érkeznek, így elsődleges stabilizálnunk őket. Ennek egyik alapvető eleme, amikor „Egyéni öngondoskodási tervet” („Self-Care Plan”) állítunk össze a kliensekkel, végigbeszélve azokat a szempontokat, amelyeket ő maga tesz vagy tehet a saját stabilitása érdekében. Dr. Odelya Gertel Kraybill az általa megalkotott „Expressive Trauma Integration” (ETI) módszerében (Gertel Kraybill, 2015) kiemelt hangsúlyt fektet az általa „Egyéni fenntarthatósági terv”-nek („Individualized Sustainability Plan”; ISP) nevezett intervencióra, amely egyaránt hangsúlyozza a kliens kognitív, érzelmi, fizikai és spirituális jóllé- 
tét. Ennek részeként fogalmazza meg a hozzánk forduló támogatását a mentálisan is stabilizáló étrend betartásának támogatásában. ${ }^{11} \mathrm{~A}$ rendszeres testmozgás és a megfelelő minőségú alvás ma már mind olyan szempontok, amit a tanácsadás során átbeszélünk a klienseinkkel. Ezekhez hasonlóan, ugyanilyen fontos és hasznos eszközünk lehet a szakirodalom alapján a klienssel közösen összeállított táplálkozási terv is. ${ }^{12}$

A táplálkozáspszichológiai intervenciós szakirodalom az alapvető szempontok tekintetében kifejezetten egységes: szinte teljesen megegyező szempontokat javasol Dr. Drew Ramsey (2016) „Eat Complete”, mint Dr. Lisa Mosconi (2018) „Brain Food” címú könyvében, de ugyanezeket a szempontokat találjuk Felice Jacka munkacsoportjának „Dietary recommendations for the prevention of depression" címú tanulmányában is (Opie és mtsai, 2017). Az alábbi, egyszerúen megvalósítható kilenc szempontot érdemes tehát átbeszélni a klienseinkkel, és ezek mentén közösen összeállítani egy „Táplálkozási öngondoskodási tervet”, ami a számára is megvalósíthatónak tû́nik.

Egyenek minél kevésbé feldolgozott ételt! Kerüljék az iparilag feldolgozott élelmiszereket, válasszanak minél több természetes alapanyagot, és fogyaszszák nyersen, illetve főzve is.

Egyenek sok zöldséget és gyümölcsöt! Az áttekintett irodalom alapján a sok zöldséget, gyümölcsöt, teljes kiőrlésú gabonákat, hüvelyeseket és olajos magvakat tartalmazó étrenddel tehetnek a legtöbbet a lelki egészségükért.

Főzzzenek otthon minél többször és többfélét! A főzés teljes figyelmet igénylő, az érzékszerveink mindegyikét ingerlő folyamat, és néhány alapvető lépés elsajátítása után jellemzően stresszcsökkentő tevékenység. Ráadásul minőségibb alapanyagokat használnak, szemben azzal, ha készételt vennének.

Egyenek többféle szinú zöldséget! Minél többféle színú zöldséget fogyasztanak (lilakáposzta, piros paradicsom, sárga kukorica, zöld spenót, rózsaszín retek, vörös cékla), annál többféle antioxidánst visznek be a szervezetükbe.

\footnotetext{
11 Letöltve: 2019. 05. 11-én: https://www.eti.training/post/why-self-care-plan-is-crucial-totrauma-therapy

12 Amennyiben a kliensról kiderül, hogy táplálkozási problémája van, akkor a leghatékonyabb ellátás biztosítása érdekében érdemes a megfelelő dietetikus szakemberrel team munkában kezelni a klienst, aki releváns, hiteles tanácsokat tud adni a betegnek a gyógyulásához. A tanulmányban megfogalmazott ajánlások táplálkozási problémával nem rendelkező kliensekre vonatkoznak.
} 
Egyenek ómega-3 zsírsavban gazdag élelmiszereket: pl. halak, olajok, olajos magvak! Mind az olajos magvak, mind pedig a halhús ${ }^{13}$ jelentós forrása az ómega-3 zsírsavaknak és ásványi anyagoknak.

Egyenek olyan ételt, ami fermentált! Olyan fermentált (erjesztett) ételek, amelyeket nem ért hőkezelés (pl. savanyított káposzta, szójaszósz, miso, joghurt, kaukázusi kefir, egyes sajtok) fontos probiotikumforrások, ezzel hozzájárulnak a kiegyensúlyozottabb bélflórához.

Válasszanak friss, szezonális és lokális termékeket! A csomagolás, tartósítás, konzerválás mind távolítják az ételt eredetétól mind térben, időben és struktúrában, csökkentve ezzel a tápanyagtartalmukat.

Egyenek sokkal kevesebb cukrot! A túlzott finomított szénhidrátfogyasztás elhízást, cukorbetegséget és depressziót okoz, ezért érdemes minimalizálni az egyszerú cukrok fogyasztását!

Egyenek lassabban! Sokkal jobb az emésztés és a felszívódás, ha az étkezésnek megadják a módját és idejét.

Mint minden viselkedésváltozást elérni szándékozó intervenció esetében, ez esetben is az alábbi kérdésekkel lépésenként támogathatjuk a kliensünket a megvalósításban: ${ }^{14}$

Mi az, amit kliensünk ezekből a szempontokból már eleve megvalósít az életében?

Mi az, amit a véleménye szerint a legkönnyebb volna újonnan beépítenie?

Mi az a legkisebb lépés, amit el tud képzelni, hogy már ezen a héten megvalósít? (Pl. heti egyszer tud vásárolni friss zöldséget, vagy heti egyszer egy cukros üdító helyett vizet iszik.)

Mi az, ami a számára múködő önjutalmazó stratégia? (Pl. szeret-e listát írni, kipipálni, pontot adni magának?)

Melyek lehetnek az akadályozó tényezók a megvalósításban? (Pl. hiányzik a tudás vagy az eszköz az otthoni fózéshez.) Milyen megoldást lehet találni ezekre a tényezőkre?

Melyek lehetnek a segítő tényezők? (Pl. együtt fogni bele a változásba egy baráttal vagy családtaggal.)

Mennyire bízik abban, hogy meg fogja tudni csinálni ezt? Mitól lenne még biztosabb a dolgában?

13 Hazánkban elérhető és ismert édesvízi halfajták: ponty, afrikai harcsa, süllő, busa és pisztráng. A hazai halfajták közül a legmagasabb telítetlen zsírsavtartalommal a busa rendelkezik, amelynek 11\%-a ómega-3 zsírsav (Magyar Dietetikusok Országos Szövetsége (MDOSZ) Táplálkozási Akadémia, 2015).

14 Letöltve: 2019. 06. 28-án: https://www.coursera.org/learn/food-and-health 
A hagyományos medikális modellek elsősorban gyógyszeres kezelésben, másodsorban pszichoterápiában, és harmadsorban gondolkodnak egyéb kezelési módszerekben. A táplálkozáspszichológiai szemléletnek azonban több elónye is van a gyógyszeres kezelésekkel szemben: (1) olcsóbb (Rodway és mtsai, 2012), (2) nincs mellékhatása (Rucklidge \& Kaplan, 2013), (3) jó hatással van a fizikai egészségre is (Jacka, Sacks, Berk, \& Allender, 2014), (4) ráadásul kontrollérzetet ad a kliensnek az élete fölött (Farmer és mtsai, 2018). Ezért érdemes megfontolnunk, hogy nemcsak elméleti, hanem praktikus szempontok okán is a hagyományos medikális és pszichoterápiás szemléletmód mellett szem előtt tartsuk a komplex életmódváltásnak ezeket a kérdéseit is. A fizikai aktivitás és az alvás minősége mellett vegyük figyelembe, hogy az étkezés is szoros összefüggésben áll a mentális egészséggel (Sánchez-Villegas, Ruíz-Canela, Gea, Lahortiga, \& Martínez-González, 2016).

Mivel a táplálkozáspszichológiai kutatások egyenlőre gyerekcipőben járnak, sok mindent nem tudunk még. Például azt, hogy milyen szerepet játszhat a genetika abban, hogy kinek elégséges az egészséges és kiegyensúlyozott táplálkozás és kinek lehet szüksége extra tápanyagbevitelre; mennyire egyedi és személyre szabott a bélflóránk összetétele; és vajon milyen szerepe lehet a bélflóra állapotának a hatékony tápanyagfelvételben („,nem az vagy, amit megeszel, hanem, az vagy, ami hatékonyan fel is szívódik a beleidben"; Rucklidge, 2014). A táplálkozáspszichológia és táplálkozáspszichiátria területe a jövőben egészen biztosan szélesedni fog, a genetikai kutatások térnyerésével egyre jobban fogjuk érteni a testünk és elménk közötti kölcsönhatásokat.

\section{8. Összefoglalás}

Összefoglalva az egy tápanyagot vizsgáló kutatások során az ómega-3 zsírsav esetében mutatnak a kísérleti eredmények még leginkább annak az irányába, hogy a fogyasztása csökkentheti a depressziós tüneteket, a legtöbb más nyomelemmel vagy vitaminnal összefüggésben egyelőre nem sikerült egyértelmú eredményeket kimutatni. Az összetettebb tápanyagprofillal dolgozó vizsgálatok egyelőre ellentmondásos eredményeket hoztak. Az utóbbi 3-4 évben éppen ezért egyre inkább átkerült a hangsúly a komplex étrendendek vizsgálatára, amelyeknek randomizált kontrollált kísérletei ígéretes eredményeket mutatnak. A bevitt zöldség-gyümölcs-arány pedig mindennél erősebb összefüggést mutat a mentális egészséggel: azok, akik több zöldséget és gyümölcsöt fogyasztanak, kevesebb mentális zavarral küzdenek, ideértve a depressziót, az észlelt stresszt és a negatív hangulatot. A zöldség-gyümölcs-bevitel, valamint a teljes kiőrlésú gabonák, hüvelyesek és olajos magvak fogyasztása pedig nemcsak a bennük található táp- 
anyagok, hanem rosttartalmuk miatt is kiemelkedő fontosságúak, mivel az elfogyasztott táplálék a bélrendszerünkön keresztül, közvetve is hat a mentális egészségre. A bélrendszerünkben élő, a mikroba és a genom szó összevonásával mikrobiomként emlegetett élő tömeget egyes kutatók már az emberi szervek közé sorolják, és egyre biztosabban látjuk, mennyire fontos szerepe van nemcsak a testi folyamatokban, de akár az idegrendszer múködésében is (ez az ún. mikrobiom-bél-agy-tengely). A mikrobiom a következő években várhatóan meghatározó kutatási területe lesz a fizikai és mentális betegségeknek is. Remélhetőleg a közeljövőben a munkánk alapját fogja képezni egy olyan pszichológiai és táplálkozási kérdőív, amellyel hatékonyan lehet következtetni a kliens mikrobiótájának állapotára és így arra is, hogy mennyire befolyásolhatja az életmódja a mentális egészségét, jóllétét.

Érdemes tehát egy olyan komplex szemléletet szem előtt tartanunk, amelyben tudatosítjuk, hogy a psziché összefügg a testtel, és a bevitt tápanyagok összességével is. Ezért tanácsadó pszichológusként munkánk részévé érdemes tennünk, hogy az étkezés kérdésével nem csupán akkor foglalkozunk, amikor valamilyen étkezési zavarral találkozunk, hanem a fenti szempontokat rutin kérdéseinkké tehetjük már az első interjú során is.

\section{Irodalom}

Akbaraly, T.N., Brunner, E.J., Ferrie, J.E., Marmot, M.G., Kivimaki, M., \& Singh-Manoux, A. (2009). Dietary pattern and depressive symptoms in middle age. The British Journal of Psychiatry, 195(5), 408-413.

Arumugam, M., Raes, J., Pelletier, E., Le Paslier, D., Yamada, T., Mende, et al. (2011). Enterotypes of the human gut microbiome. Nature, 473(7346), 174-180.

Belkaid, Y., \& Hand, T.W. (2014). Role of the microbiota in immunity and inflammation. Cell, 157(1), 121-141.

Bezzegh, A. (2013). A B12 vitamin és a folsav anyagcsere aktuális kérdései. Medical online. Letöltve: 2019. 01. 10-én: http://medicalonline.hu/gyogyitas/cikk/a_b12_vitamin_ es_a_folsav_anyagcsere_aktualis_kerdesei

Bíró, Gy. (2014). A bél mikrobióta kapcsolata az egészséggel és betegséggel. Irodalmi áttekintés. Egészségtudomány, 56(3). Letöltve: 2019. 01. 10-én: http://egeszsegtudomany. higienikus.hu/cikk/2014-3/Biro.pdf

Bishwajit, G., O'Leary, D.P., Ghosh, S., Sanni, Y., Shangfeng, T., \& Zhanchun, F. (2017). Association between depression and fruit and vegetable consumption among adults in South Asia. BMC Psychiatry, 17(1), 15. Doi: 10.1186/s12888-017-1198-1

Blanchflower, D.G., Oswald, A.J., \& Stewart-Brown, S. (2013). Is psychological well-being linked to the consumption of fruit and vegetables? Social Indicators Research, 114(3), 785-801.

Brookie, K.L., Best, G.I., \& Conner, T.S. (2018). Intake of raw fruits and vegetables is associated with better mental health than intake of processed fruits and vegetables. Frontiers in Psychology, 9, 487. Doi: doi:10.3389/fpsyg.2018.00487

Christensen, L. (2001). The effect of food intake on mood. Clinical Nutrition, 20, 161-166. 
Clapp, M., Aurora, N., Herrera, L., Bhatia, M., Wilen, E., \& Wakefield, S. (2017). Gut microbiota's effect on mental health: The gut-brain axis. Clinics and Practice, 7(4), 987. doi:10.4081/cp.2017.987

Dave, M., Higgins, P.D., Middha, S., \& Rioux, K.P. (2012). The human gut microbiome: current knowledge, challenges, and future directions. Translational Research, 160(4), 246-257.

Del Chierico, F., Vernocchi, P., Dallapiccola, B., \& Putignani, L. (2014). Mediterranean diet and health: food effects on gut microbiota and disease control. International Journal of Molecular Sciences, 15(7), 11678-11699.

Dewanto, V., Wu, X., Adom, K.K., \& Liu, R.H. (2002). Thermal processing enhances the nutritional value of tomatoes by increasing total antioxidant activity. Journal of Agricultural and Food Chemistry, 50(10), 3010-3014.

Farmer, N., Touchton-Leonard, K., \& Ross, A. (2018). Psychosocial benefits of cooking interventions: a systematic review. Health Education and Behavior, 45(2), 167-180.

Ford, P.A., Jaceldo-Siegl, K., Lee, J.W., Youngberg, W., \& Tonstad, S. (2013). Intake of Mediterranean foods associated with positive affect and low negative affect. Journal of Psychosomatic Research, 74(2), 142-148.

Forsyth, A., Deane, F.P., \& Williams, P. (2015). A lifestyle intervention for primary care patients with depression and anxiety: A randomised controlled trial. Psychiatry Research, 230(2), 537-544.

Frecska, E., \& Móré, Cs. (2018). A bélflóra szerepe a mentális egészségben. Lege Artis Medicinae, 28(1-2), 11-15.

Fristad, M.A., Vesco, A.T., Young, A.S., Healy, K.Z., Nader, E.S., Gardner, W., et al. (2019). Pilot randomized controlled trial of omega-3 and individual-family psychoeducational psychotherapy for children and adolescents with depression. Journal of Clinical Child and Adolescent Psychology, 48(S1), 105-118.

Gardner, M.P., Wansink, B., Kim, J., \& Park, S.B. (2014). Better moods for better eating?: How mood influences food choice. Journal of Consumer Psychology, 24(3), 320-335.

Gertel Kraybill, O. (2015). Experiential Training to Address Secondary Traumatic Stress in Aid Personnel. (Doctoral Dissertation). Lesley University, Cambridge. Letöltve: 2019. 06. 28-án: https:/ / pdfs.semanticscholar.org/08e5/83e1933d03fe01e1453f0e0f8886791a6686. pdf

Gilbert, J.A., Blaser, M.J., Caporaso, J.G., Jansson, J.K., Lynch, S.V., \& Knight, R. (2018). Current understanding of the human microbiome. Nature Medicine, 24(4), 392-400.

Gopinath, B., Flood, V.M., Burlutksy, G., Louie, J.C.Y., \& Mitchell, P. (2016). Association between carbohydrate nutrition and prevalence of depressive symptoms in older adults. The British Journal of Nutrition, 116(12), 2109-2114.

Graf, D., Di Cagno, R., Fåk, F., Flint, H.J., Nyman, M., Saarela, M., et al. (2015). Contribution of diet to the composition of the human gut microbiota. Microbial ecology in health and disease, 26, 26164. Doi: 10.3402/mehd.v26.26164

Hu, F.B. (2002). Dietary pattern analysis: a new direction in nutritional epidemiology. Current Opinion in Lipidology, 13(1), 3-9.

Institute of Medicine, Food and Nutrition Board (2002). Dietary Reference Intakes: Energy, Carbohydrates, Fiber, Fat, Fatty Acids Cholesterol, Protein and Amino Acids. Washington, DC: National Academies Press

Jacka, F.N. (2018). Targeting the gut to achieve improved outcomes in mood disorders. Bipolar Disorders, 21(1), 88-89.

Jacka, F.N., Mykletun, A., Berk, M., Bjelland, I., \& Tell, G.S. (2011). The association between habitual diet quality and the common mental disorders in community-dwelling adults: the Hordaland Health study. Psychosomatic Medicine, 73(6), 483-490. 
Jacka, F.N., O’Neil, A., Opie, R., Itsiopoulos, C., Cotton, S., Mohebbi, M., et al. (2017). A randomised controlled trial of dietary improvement for adults with major depression (the 'SMILES' trial). BMC Medicine, 15(1), 23. Doi: doi: 10.1186/s12916-017-0791-y

Jacka, F.N., Pasco, J.A., Mykletun, A., Williams, L.J., Hodge, A.M., O’Reilly, S.L., et al. (2010). Association of Western and traditional diets with depression and anxiety in women. The American Journal of Psychiatry, 167(3), 305-311.

Jacka, F.N., Sacks, G., Berk, M., \& Allender, S. (2014). Food policies for physical and mental health. BMC Psychiatry, 14(1), 132. Doi: 10.1186/1471-244X-14-132

Jing, L., Yuwei, L., Zhenping, H., \& Qian, W. (2017). Impact of heat processing on the bioavailability of zinc and iron from cereals and pulses. International Food Research Journal, 24(5), 1980-1985.

Katz, Dl., \& Meller, S. (2014). Can we say what diet is best for health? Annual Review of Public Health, 35(1), 83-103.

Knight, R. (2014). How our microbes make us who we are. Presented at the Ted Talk. Letöltve: 2019. 02. 11-én: https://www.ted.com/talks/rob_knight_how_our_microbes_make_ us_who_we_are?language $=$ en\#t-300792

Knight, R., \& Buhler, B. (2015). Szerves részünk: Hogyan befolyásolják életünket a mikrobák? Budapest: HVG Könyvek

Knight, R., \& McDonald, D. (é.n.) Our second genome. Imagine - Johns Hopkins University Center for Talented Youth. Letöltve: 2019. 02. 11-én: https:/ /cty.jhu.edu/imagine/docs/ second-genome.pdf

Knight, R., Metcalf, J.L., \& Amato, K.R. (2018). Gut check: Exploring your microbiome. Online Course presented at the Coursera, Center for Microbiome Innovation, University of California, San Diego. Letöltve: 2019. 03. 11-én: https:/ /www.coursera.org/learn/ microbiome

Kohlné Papp, I. (2016). A falászavar jellemzői és kezelési lehetőségei. Új Diéta, (2-3), 25-27.

KSH (2018). Egészségi állapot és egészségmagatartás, 2016-2017. Statisztikai Tükör. Letöltve: 2019. 04.11-én: https://www.ksh.hu/docs/hun/xftp/stattukor/egeszsegallapot1617. pdf

Lai, J.S., Hiles, S., Bisquera, A., Hure, A. J., McEvoy, M., \& Attia, J. (2014). A systematic review and meta-analysis of dietary patterns and depression in community-dwelling adults. The American Journal of Clinical Nutrition, 99(1), 181-197.

Le Port, A., Gueguen, A., Kesse-Guyot, E., Melchior, M., Lemogne, C., Nabi, H., et al. (2012). Association between dietary patterns and depressive symptoms over time: A 10-year follow-up study of the GAZEL cohort. PLoS One, 7(12), e51593. Doi: 10.1371/journal. pone.0051593

Lesani, A., Mohammadpoorasl, A., Javadi, M., Esfeh, J.M., \& Fakhari, A. (2016). Eating breakfast, fruit and vegetable intake and their relation with happiness in college students. Eating and Weight Disorders, 21(4), 645-651.

Li, Y., Lv, M.R., Wei, Y.-J., Sun, L., Zhang, J.-X., Zhang, H.-G., \& Li, B. (2017). Dietary patterns and depression risk: A meta-analysis. Psychiatry Research, 253, 373-382.

Livny, O., Reifen, R., Levy, I., Madar, Z., Faulks, R., Southon, S., et al. (2003). Beta-carotene bioavailability from differently processed carrot meals in human ileostomy volunteers. European Journal of Nutrition, 42(6), 338-345.

Lukács, L. (2017). A diéta mint krízis. Mentálhigiéné és Pszichoszomatika, 18(2), 105-124.

Magyar Dietetikusok Országos Szövetsége (2015). Táplálkozási Akadémia, Hírlevél, 8(12). Letöltve: 2019. 05. 14-én: https://mdosz.hu/hun/wp-content/uploads/2016/03/ taplalkozasi_akademia_2015_12_halak_151215.pdf 
Malan-Muller, S., Valles-Colomer, M., Raes, J., Lowry, C. A., Seedat, S., \& Hemmings, S.M.J. (2018). The gut microbiome and mental health: Implications for anxiety- and traumarelated disorders. Omics, 22(2), 90-107.

McMartin, S.E., Jacka, F.N., \& Colman, I. (2013). The association between fruit and vegetable consumption and mental health disorders: evidence from five waves of a national survey of Canadians. Preventive Medicine, 56(3-4), 225-230.

Mikolajczyk, R.T., El Ansari, W., \& Maxwell, A. E. (2009). Food consumption frequency and perceived stress and depressive symptoms among students in three European countries. Nutrition Journal, 8, 31. Doi: 10.1186/1475-2891-8-31

Mocking, R.J.T., Harmsen, I., Assies, J., Koeter, M.W.J., Ruhé, H.G., \& Schene, A.H. (2016). Meta-analysis and meta-regression of omega-3 polyunsaturated fatty acid supplementation for major depressive disorder. Translational Psychiatry, 6(3), e756. Doi: 10.1038/ tp.2016.29

Morris M.S, Fava M, Jacques P.F, Selhub J, \& Rosenberg I.H. (2003). Depression and folate status in the US population. Psychotherapy and Psychosomatics, 72(2), 80-87.

Mosconi, L. (2018). Brain Food: The Surprising Science of Eating for Cognitive Power. New York: Penguin Life

Mujcic, R., \& Oswald, A. (2016). Evolution of well-being and happiness after increases in consumption of fruit and vegetables. American Journal of Public Health, 106(8), 1504-1510.

Murakami K., Mizoue T., Sasaki S., Ohta M., Sato M., Matsushita Y. et al. (2008) Dietary intake of folate, other B vitamins, and omega-3 polyunsaturated fatty acids in relation to depressive symptoms in Japanese adults. Nutrition, 24(2), 140-147.

O’Neil, A., Quirk, S.E., Housden, S., Brennan, S.L., Williams, L.J., Pasco, J.A., et al. (2014). Relationship between diet and mental health in children and adolescents: A systematic review. American Journal of Public Health, 104(10), e31-e42.

Opie, R.S., Itsiopoulos, C., Parletta, N., Sanchez-Villegas, A., Akbaraly, T.N., Ruusunen, A., et al. (2017). Dietary recommendations for the prevention of depression. Nutritional Neuroscience, 20(3), 161-171.

Parletta, N., Zarnowiecki, D., Cho, J., Wilson, A., Bogomolova, S., Villani, A. et al. (2019). A Mediterranean-style dietary intervention supplemented with fish oil improves diet quality and mental health in people with depression: A randomized controlled trial (HELFIMED). Nutritional Neuroscience, 22(7), 474-487.

Pollan, M. (2008). In defense of food: An eater's manifesto. New York: Penguin Press

Popa, T., \& Ladea, M. (2012). Nutrition and depression at the forefront of progress. Journal of Medicine and Life, 5(4), 414-419.

Psaltopoulou, T., Sergentanis, T. N., Panagiotakos, D. B., Sergentanis, I. N., Kosti, R., \& Scarmeas, N. (2013). Mediterranean diet, stroke, cognitive impairment, and depression: A meta-analysis. Annals of Neurology, 74(4), 580-591.

Rahe, C., Unrath, M., \& Berger, K. (2014). Dietary patterns and the risk of depression in adults: a systematic review of observational studies. European Journal of Nutrition, 53(4), 997-1013.

Ramsey, D. (2016). Eat Complete: The 21 Nutrients That Fuel Brainpower, Boost Weight Loss, and Transform Your Health. New York: HarperCollins Publishers Inc.

Rinninella, E., Raoul, P., Cintoni, M., Franceschi, F., Miggiano, G., Gasbarrini, A., et al. (2019). What is the healthy gut microbiota composition? A changing ecosystem across age, environment, diet, and diseases. Microorganisms, 7(1), 14. Doi: 10.3390/micro organisms7010014

Rodway, M., Vance, A., Watters, A., Lee, H., Bos, E., \& Kaplan, B.J. (2012). Efficacy and cost of micronutrient treatment of childhood psychosis. Case Reports, 2012, bcr2012007213. Doi: 10.1136/bcr-2012-007213 
Rogers, G.B., Keating, D.J., Young, R.L., Wong, M.-L., Licinio, J., \& Wesselingh, S. (2016). From gut dysbiosis to altered brain function and mental illness: mechanisms and pathways. Molecular Psychiatry, 21(6), 738-748.

Rucklidge, J.J. (2014). The surprisingly dramatic role of nutrition in mental health. Presented at the TEDxTalk. Letöltve: 2019. 03. 14-én: https://www.youtube.com/watch?v= 3dqXHHCc5lA

Rucklidge, J.J., \& Kaplan, B.J. (2013). Broad-spectrum micronutrient formulas for the treatment of psychiatric symptoms: a systematic review. Expert Review of Neurotherapeutics, 13(1), 49-73.

Rucklidge, J.J., Andridge, R., Gorman, B., Blampied, N., Gordon, H., \& Boggis, A. (2012). Shaken but unstirred? Effects of micronutrients on stress and trauma after an earthquake: RCT evidence comparing formulas and doses. Human Psychopharmacology: Clinical and Experimental, 27(5), 440-454.

Rucklidge, J.J., Frampton, C.M., Gorman, B., \& Boggis, A. (2014). Vitamin-mineral treatment of attention-deficit hyperactivity disorder in adults: double-blind randomised placebocontrolled trial. The British Journal of Psychiatry, 204(4), 306-315.

Sal, I \& Kohlné Papp, I. (2017). A cukorbetegség magatartás-orvoslási megközelítése. Lege Artis Medicinx, 27(2-2), 6-16.

Sánchez-Villegas A., Doreste, J., Schlatter, J., Pla J. \& Bes-Rastrollo, M. \& Martínez-González, M.A. (2009). Association between folate, vitamin B6 and vitamin B12 intake and depression in the SUN cohort study. Journal of Human Nutrition and Dietetics, 22, 122-133.

Sánchez-Villegas, A., Ruíz-Canela, M., Gea, A., Lahortiga, F., \& Martínez-González, M.A. (2016). The association between the mediterranean lifestyle and depression. Clinical Psychological Science, 4(6), 1085-1093.

Sánchez-Villegas, A., Toledo, E., de Irala, J., Ruiz-Canela, M., Pla-Vidal, J., \& MartínezGonzález, M.A. (2012). Fast-food and commercial baked goods consumption and the risk of depression. Public Health Nutrition, 15(3), 424-432.

Sarris J., Mischoulon D., Schweitzer I. (2012) Omega-3 for bipolar disorder: meta-analyses of use in mania and bipolar depression. Journal of Clinical Psychiatry, 73(1), 81-86.

Sarris, J., Murphy, J., Mischoulon, D., Papakostas, G.I., Fava, M., Berk, M. et al. (2016). Adjunctive nutraceuticals for depression: A systematic review and meta-analyses. American Journal of Psychiatry, 173(6), 575-587.

Sarris J., Schoendorfer N., Kavanagh D.J. (2009) Major depressive disorder and nutritional medicine: a review of monotherapies and adjuvant treatments. Nutrition Reviews, 67(3), 125-131.

Sawicki, C.M., Livingston, K.A., Obin, M., Roberts, S.B., Chung, M., \& McKeown, N.M. (2017). Dietary fiber and the human gut microbiota: Application of evidence mapping methodology. Nutrients, 9(2). Doi: 10.3390/nu9020125

Schefft, C., Kilarski, L.L., Bschor, T., \& Köhler, S. (2017). Efficacy of adding nutritional supplements in unipolar depression: A systematic review and meta-analysis. European Neuropsychopharmacology, 27(11), 1090-1109.

Sender, R., Fuchs, S., \& Milo, R. (2016). Revised estimates for the number of human and bacteria cells in the body. PLoS Biology, 14(8), e1002533. Doi: 10.1371/journal.pbio.1002533

Sublette, M.E., Ellis ,S.P., Geant, A.L., Mann, J.J. (2011) Meta-analysis of the effects of eicosapentaenoic acid (EPA) in clinical trials in depression. Journal of Clinical Psychiatry, 72(12), 1577-1584.

Szeitz-Szabó, M., Bíró, L., Bíró, Gy., \& Sali, J. (2011). Dietary survey in Hungary, 2009. Part I. Macronutrients, alcohol, caffeine, fibre. Acta Alimentaria, 40(1), 142-152. 
Trichopoulou, A., Naska, A., Antoniou, A., Friel, S., Trygg, K., \& Turrini, A. (2003). Vegetable and fruit: the evidence in their favour and the public health perspective. International Journal for Vitamin and Nutrition Research, 73(2), 63-69.

Turkmen, N., Poyrazoglu, E.S., Sari, F., \& Velioglu, Y.S. (2006). Effects of cooking methods on chlorophylls, pheophytins and colour of selected green vegetables. International Journal of Food Science \& Technology, 41(3), 281-288.

Túry, F., \& Czeglédi, E. (2017). Az elhízás pszichszomatikája és pszichoterápiás lehetőségei. In J.R. Bedros (Eds.), Klinikai obezitológia (147-166). Budapest: Semmelweis Kiadó

Túry, F., Szumska, I., Pászthy, B., \& Purebl, Gy. (2017). Irányelvek és ajánlások az evészavarok kezelésében. Psychiatria Hungarica, 32(4), 440-450.

White, B.A., Horwath, C.C., \& Conner, T.S. (2013). Many apples a day keep the blues away - daily experiences of negative and positive affect and food consumption in young adults. British Journal of Health Psychology, 18(4), 782-798.

WHO (2003). Diet, nutrition and the prevention of chronic diseases. Report of a Joint WHO/ FAO Expert Consultation. WHO Technical Report Series 916. Geneva, Letöltve: 2019. 05. 14-én: https:/ / apps.who.int/iris/bitstream/handle/10665/42665/WHO_TRS_916. pdf;jsessionid=381813B9D6F619DCBF186B81E0B2CF62? sequence $=1$

Young, A.S., Arnold, L.E., Wolfson, H.L., \& Fristad, M.A. (2017). Psychoeducational psychotherapy and omega-3 supplementation improve co-occurring behavioral problems in youth with depression: Results from a pilot RCT. Journal of Abnormal Child Psychology, 45(5), 1025-1037.

Zinöcker, M.K., \& Lindseth, I.A. (2018). The Western diet-microbiome-host interaction and its role in metabolic disease. Nutrients, 10(3), 365. Doi: 10.3390/nu10030365

\section{Köszönetnyilvánítás}

Köszönettel tartozom Gáspár Bence biológusnak a tanulmány elkészültében nyújtott segítségéért.

\section{Nyilatkozat érdekütközésról}

A szerző ezúton kijelenti, hogy esetében nem állnak fenn érdekütközések. 


\title{
The relevance of nutrition psychology in therapeutic settings
}

\author{
VIDA, KATALIN
}

The relatively new field of nutritional psychology and nutritional psychiatry has a growing number of research supporting the connection between vegetable/fruit consumption and mental health. The results of the single-nutrient studies, apart from those of omega- 3 fatty acids, have not been able to produce unambiguous results so far. In contrast, complex research designs focusing on the relationships between overall dietary quality and mental disorders have revealed promising results. The consumption of the vegetables-fruits, whole grains, legumes and oil seeds could be one of the key factors in this respect since the dietary fibre found primarily in plant foods feeds billions of bacteria in our guts. The evidence for the role of gut bacteria in modulating brain health and behavior is extensive - the microbiome-gut-brain axis (MGBA) consists of bidirectional communication between the central and the enteric nervous system, linking emotional and cognitive centres of the brain with peripheral intestinal functions. Therefore this paper argues that psychologists are strongly advised to consider the dietary habits of the client, even if this is not in the focus of their symptoms.

Keywords: nutritional psychology, microbiome, microbiome-gut-brain axis, depression, anxiety, counseling, psychotherapy

A cikk a Creative Commons Attribution 4.0 International License (https:/ / creativecommons.org/ licenses/by/4.0/) feltételei szerint publikált Open Access közlemény, melynek szellemében a cikk bármilyen médiumban szabadon felhasználható, megosztható és újraközölhető, feltéve, hogy az eredeti szerzó és a közlés helye, illetve a CC License linkje és az esetlegesen végrehajtott módosítások feltüntetésre kerülnek. (SID_1) 
